\title{
ANALISIS KEPEMIMPINAN TRANSFORMASIONAL DAN PENGEMBANGAN SUMBERDAYA MANUSIA TERHADAP KINERJA PEGAWAI PADA DINAS PEKERJAAN UMUM PROVINSI SULAWESI TENGGARA
}

\author{
${ }^{1}$ La Ode Muhammad Elwan, ${ }^{2}$ Bakti, ${ }^{3}$ Taufik \\ 1,2,3, Fakultas IImu Sosial dan IImu Politik Universitas Halu Oleo \\ muh.elwan@uho.ac.id, Bakti.pascasarjana@gmail.com, taufikfisip@gmail.com \\ Kendari - Indonesia
}

\begin{abstract}
The purpose of the study was to analyze the effect of transformational leadership and human resource development on the performance of employees of the Public Works Office of Southeast Sulawesi Province. The design of this study is associative explanative research. The population of this study was a staff of the Public Works Agency of the Southeast Sulawesi Province. The study sample was selected by cluster random sampling according to the level of education using the Taro Yamane formula. Thus a sample of 88 people. Besides that, 8 informants were used. Data collection using questionnaires, interviews and documentation. Data analysis using multiple linear regression analysis followed by t-test (partial) and F test (simultaneous). The results of the study show that: (1) Transformational leadership has a significant effect on the performance of employees of the Public Works Office of Southeast Sulawesi Province. (2) The development of human resources observed through the dimensions of education and training has a significant effect on the performance of employees of the Public Works Office of Southeast Sulawesi Province. (3) Transformational leadership and human resource development simultaneously have a significant effect on the performance of employees of the Public Works Office of Southeast Sulawesi Province.
\end{abstract}

Keywords: Human Resource Development; Performance; Transformational Leadership

\begin{abstract}
Abstrak
Tujuan penelitian untuk menganalisis pengaruh kepemimpinan transformasional dan pengembangan sumberdaya manusia terhadap kinerja pegawai Dinas Pekerjaan Umum Provinsi Sulawesi Tenggara. Desain penelitian ini adalah penelitian eksplanatif asosiatif. Populasi penelitian ini adalah pegawai staf Dinas Pekerjaan Umum Provinsi Sulawesi Tenggara. Sampel penelitian dipilih secara acak berkelompok (cluster random sampling) sesuai tingkat pendidikan dengan menggunakan rumus Taro Yamane. Dengan demikian sampel sebanyak 88 orang. Disamping itu digunakan informan sebanyak 8 orang. Pengumpulan data menggunakan angket, wawancara dan dokumentasi. Analisis data menggunakan analisis regresi linear berganda dilanjutkan dengan uji $\dagger$ (parsial) dan uji $F$ (simultan). Hasil penelitian menunjukkan bahwa: (1) Kepemimpinan transformasional berpengaruh signifikan terhadap kinerja pegawai Dinas Pekerjaan Umum Provinsi Sulawesi Tenggara. (2) Pengembangan sumberdaya manusia yang diamati melalui dimensi pendidikan dan pelatihan berpengaruh signifikan terhadap kinerja pegawai Dinas Pekerjaan Umum Provinsi Sulawesi Tenggara. (3) Kepemimpinan transformasional dan pengembangan sumberdaya manusia secara simultan berpengaruh signifikan terhadap kinerja pegawai Dinas Pekerjaan Umum Provinsi Sulawesi Tenggara.
\end{abstract}

Kata Kunci: Pengembangan Sumberdaya Manusia; Kinerja; Kepemimpinan Transformasional

Open Access at: http://ojs.uho.ac.id/index.php/PUBLICUHO/index

Journal Publicuho is licensed under a Creative Commons Attribution 4.0 International License. 


\section{PENDAHULUAN}

Dinas Pekerjaan Umum Provinsi Sulawesi Tenggara adalah salah satu instansi pemerintah yang di dalamnya terdapat 621 orang staf (diluar pimpinan, kepala bidang dan kepala seksi) yang terdistribusi pada golongan II sebanyak 185 orang dan golongan III sebanyak 436 orang. Berdasarkan informasi yang ditemukan dari pra penelitian yang dilakukan menunjukkan bahwa kinerja sebagian kecil pegawai pada Dinas Pekerjaan Umum Provinsi Sulawesi Tenggara belum sepenuhnya sesuai yang diharapkan bila diamati dari kualitas, kuantitas kerja, ketepatan waktu menyelesaikan pekerjaan, kebutuhan akan supervisi dan pengaruh individual. Pada aspek kualitas kerja antara lain terlihat bahwa masih terdapat pegawai yang harus diperintah dalam menyelesaikan tugas yang menjadi kewajibannya, bekerja tidak tepat waktu yang ditandai dengan terlambat masuk kantor, pulang sebelum waktunya dan pada saat jam kantor sedang berlangsung ada yang terlihat tidak bekerja. Berkaitan dengan hal ini maka berdasarkan laporan akuntabilitas kinerja nampak bahwa persentase pencapaian hasil pekerjaan baru mencapai $85 \%$. Disamping itu, data menunjukkan bahwa selama tiga bulan terakhir jumlah pegawai absen meningkat, dimana pada bulan September sebanyak 53 orang, kemudian pada bulan Oktober menjadi 61 orang dan pada bulan November tercatat 67 orang. Selanjutnya pada dimensi kuantitas kerja antara lain terlihat bahwa pelayanan prima kepada masyarakat belum teraplikasi dengan baik yaitu pelayanan terkesan lambat dan birokratis. Pada aspek ketepatan waktu terlihat masih adanya tunggakan kerja yaitu yang seharusnya pekerjaan selesai pada hari itu namun dalam kenyataan diselesaikan keesokan harinya. Pada aspek kebutuhan pengawasan masih banyak pegawai yang harus diawasi untuk dapat bekerja dengan hasil yang maksimal. Penilaian kinerja tentunya dilakukan oleh atasan masing-masing pegawai. Fenomena tersebut merupakan kondisi nyata yang terjadi dan ada kaitannya dengan praktek kepemimpinan dan kebijakan pengembangan sumberdaya manusia. Namun demikian masih perlu diteliti lebih lanjut.

Berdasarkan uraian pada latar belakang, maka yang menjadi permasalahan dalam penelitian ini dirumuskan sebagai berikut :

1. Apakah kepemimpinan transformasional berpengaruh terhadap kinerja pegawai Dinas Pekerjaan Umum Provinsi Sulawesi Tenggara.

2. Apakah pengembangan sumberdaya manusia berpengaruh terhadap kinerja pegawai Dinas Pekerjaan Umum Provinsi Sulawesi Tenggara.

3. Apakah kepemimpinan transformasional dan pengembangan sumberdaya manusia secara bersamaan berpengaruh terhadap kinerja pegawai Dinas Pekerjaan Umum Provinsi Sulawesi Tenggara. 
Pada bagian ini, kemudian memberikan penjelasan umum bagaimana analisis kepemimpinan transformasional dan pengembangan sumberdaya manusia terhadap kinerja pegawai sebuah lembaga pemerintah untuk membangun pemahaman bersama subtansi kajian penelitian ini.

\section{Konsep Kepemimpinan Transformasional}

Tanggung jawab utama dari seorang pimpinan organisasi adalah mengarahkan bawahannya ke arah pencapaian tujuan organisasi dengan jalan mengaktualisasikan misi, visi, strategi dan sasaran (Zaccaro dan Bader, 2004). Pimpinan pada setiap tingkatan bertanggungjawab atas diseminasi tujuan strategis organisasi dan meyakinkan para pengikutnya untuk mengimplementasikan tujuan tersebut secara efektif (Bersona dan Avolio, 2004).

Cannella dan Monroe (2002) mengindikasikan bahwa kepemimpinan transformasional mampu membangun hubungan-hubungan dengan pengikutnya sedemikian rupa sehingga mereka dapat lebih mudah untuk mendiseminasi dan mengimplementasikan tujuan-tujuan strategis.

Pimpinan dengan transformasional didefinisikan dengan seorang pemimpin yang memiliki visi kepemimpinannya secara realistis dan dapat meyakinkan serta menuntun organisasi mencapai suatu cita-cita masa depan yang lebih baik dari kondisinya pada masa kini. Kepemimpinan transformasional selalu konsisten dan fokus terhadap kendala anggaran seperti yang terjadi pada model kepemimpinan karismatik dan strategik (Aditiawan Chandra, 2002)

Sejalan dengan itu Aditiawan Chandra (2002) juga menyajikan karakteristik utama seorang pemimpin transformasional dalam menghadapi tantangan dan peluang yaitu : integritas, kompeten, konsisten, loyal dan keterbukaan. Hal ini penting dipahami karena pimpinan transformasional harus mampu merangsang bawahan untuk menghasilkan karya-karya nyata secara inovatif. Para bawahan profesional harus mampu mengakomodir ego dan kepentingan individu-individu atau kelompok organisasi untuk merealisir visi organisasi.

Seorang transformational leader perlu memiliki keahlian dalam memimpin tim organisasi yang terdiri dari para tenaga profesional melalui pendekatan pribadi, memecahkan konflik yang timbul antar anggota organisasi, mendengarkan segala keluhan, memberikan umpan balik dan melaksanakan tehnik oral persuasion sehingga organisasi bisa berjalan lebih efisien dan efektif. Efektivitas implementasi sasaran strategis organisasi tergantung sebaik apa para pimpinan dalam suatu organisasi melihat dan mengartikan sasaran-sasaran, menerjemahkannya ke dalam sasaran-sasaran yang lebih spesifik untuk tiap-tiap unit kerja dan mendorong lingkungan belajar yang ditujukan untuk pencapaian keberhasilan pelaksanaan tugas. 
Avolio (2004) menyatakan bahwa pimpinan yang memiliki sifat transformasional mampu mengartikulasi visi strategis yang dapat membantu bawahan untuk fokus belajar tentang apa yang penting dalam mengimplementasikan visi dan misi pada tiap level. Pimpinan transformasional mendorong bawahannya untuk senantiasa mempertanyakan asumsiasumsi, metode-metode dan sasaran-sasaran dalam usaha mencari cara yang lebih baik untuk memahami dan menterjemahkannya ke dalam tindakan-tindakan yang spesifik.

Usaha-usaha untuk memahami pengaruh sosial dan kepemimpinan merupakan hal yang parallel dalam sejarah umat manusia, tetapi aplikasi pendekatan-pendekatan sainstifik dalam pengembangan pengetahuan tentang kepemimpinan merupakan fenomena abad kedua puluh (Bryman, 2006:53). Pandangan bahwa individu atau ciri/sifat fisik mungkin dapat menjelaskan atau memprediksi kapasitas kepemimpinan tetap mendapatkan perhatian di abad kedua puluh (Zaccaro, Kemp dan Bader, 2004:101). Kesalahan interprestasi tentang peran sifat dalam kepemimpinan dan kurangnya alat-alat statistik dalam mengintegrasikan koefisien-koefisien korelasi independent, membuat teori sifat (trait theory) tertinggal dipertengahan abad kedua puluh.

Perhatian terhadap kepemimpinan transformasional mendominasi pendekatan-pendekatan ilmiah dalam usaha memahami kepemimpinan selama hampir dua dekade terakhir ini (Hunt, 2004). Sementara penelitian-penelitian tentang interaksi pimpinan-bawahan dengan menggunakan Multifactorial Leadership Questionnaire (MLQ) menunjukkan hasil yang menjanjikan, masih ada sejumlah variasi yang substansial dalam interaksi tersebut yang masih perlu diteliti (Bass dan Avolio, 2006).

Sebagaimana pendekatan-pendekatan karismatik dan kepemimpinan transformasional berkembang dan mendekati kejenuhan, banyak saran bermunculan untuk menggunakan pendekatan-pendekatan yang lebih holistik untuk mempertimbangkan kapasitas kepemimpinan serta proses kepemimpinan (Yukl, 2004). Salah satu kemungkinan adalah dengan melihat kepemimpinan bukan saja sebagai interaksi, tetapi lebih sebagai fungsi dari serangkaian keahlian yang dimiliki dan digunakan oleh pimpinan secara individu (Brown, Bryant dan Reilly, 2006). Jika pemahaman akan kepemimpinan dikonsentrasikan bukan hanya pada apa yang dilakukan oleh pimpinan, tetapi lebih pada pertimbangan atas kapabilitas apa yang harus dimiliki oleh seseorang agar dapat melakukan peran kepemimpinan yang efektif, mungkin pemahaman, pemilihan serta pengembangan akan dapat dilakukan lebih baik.

Bass (2005) dengan teori kepemimpinan transformasional menekankan efek dramatik dari seorang pimpinan terhadap bawahannya. Dalam hal ini, menurut Bass dan Avolio (2004) pimpinan transformasional mencapai hasil yang superior dengan cara mempengaruhi bawahan melalui empat cara utama, yaitu idealized, influence (model dan peran menimbulkan proses identifikasi personal), inspirational motivation (menimbulkan semangat 
tim serta menciptakan kesatuan visi), intellectual stimulation (mendorong kreativitas dan perumusan masalah) dan individual consideration (pembimbingan serta aktivitas-aktivitas pengembangan).

Manfaat kepemimpinan transformasional dianggap telah memperluas serta meningkatkan kepentingan bawahan, menimbulkan kesadaran serta penerimaan diantara bawahan akan tujuan serta misi dari kelompok dan memotivasi bawahan untuk bekerja melebihi interes pribadinya bagi kebaikan kelompok maupun organisasi (House, 2001). Kepemimpinan transformasional mengartikulasikan visi masa depan yang realistic yang dapat dipahami bersama, menstimulasi bawahan secara intelektual dan memberikan perhatian atas perbedaan-perbedaan yang ada di antara bawahan.

Rafferty dan Griffin (2004) menggaris bawahi efek transformasi dari para pimpinan transformasional bagi organisasi dan juga bagi individu. Sering dikatakan bahwa dengan mendefinisikan kebutuhan untuk berubah, penciptaan visi-visi baru dan memobilisasi komitmen bagi visi-visi tersebut, para pimpinan akan dapat mentransformasi organisasi. Pendapat tersebut menunjukkan bahwa kepemimpinan transformasional memberikan efek pada bagi organisasi dan juga bagi individu.

Menurut Bass (2005) proses transformasi bawahan dapat dicapai melalui peningkatan kesadaran akan pentingnya serta nilai dari hasil yang diharapkan, membawa bawahan untuk meningkatkan keinginan pribadinya dan mengangkat atau meningkatkan kebutuhan bawahan.

Persepktif pengukuran yang cukup berpengaruh tentang kepemimpinan transformasional dikembangkan oleh Bernard Bass dan rekan-rekan. Model kepemimpinan dalam skala luas yang mereka kembangkan menempatkan kepemimpinan transformasional, transaksional dan laissez-faire dalam sebuah kontinum kepemimpinan aktif-pasif dan menggambarkan bagaimana tipe-tipe kepemimpinan ini berhubungan (Avolio, 2006).

Banyak hasil penelitian menyangkut perbedaan dari beberapa tipe kepemimpinan menunjukkan bahwa kepemimpinan transformasional jauh lebih efektif dibanding kepemimpinan transaksional (Shamir dan House, 2003). House (2001) mencatat paling tidak ada lebih dari seratus pengujian empiris menunjukkan bahwa kepemimpinan yang digambarkan sebagai karismatik, transformasional atau visionary memiliki efek positif atas performa organisasi, kepuasan bawahan dan komitmen bawahan.

Dua penelitian meta-analisis yang dilakukan oleh Fuller, dkk (2006) dan Lowe, dkk (2006) mendukung konklusi ini. Dalam meta analisis ini ditemukan bahwa terdapat korelasi yang sangat kuat antara kepemimpinan transformasional dengan persepsi bawahan atas efektifitas pimpinannya dan kepuasan kerja bawahan. Penelitian juga menunjukkan bahwa kepemimpinan transformasional mendekati persepsi bawahan atas kepemimpinan yang ideal (Bass dan Avolio, 2000). 
Walaupun teori-teori kepemimpinan transformasional seperti yang dikembangkan oleh Bass (2005), Bennis dan Nanus (2000), Burns (2003) dan House (2001) saling melengkapi, tetapi masing-masing menggunakan kumpulan perilaku pimpinan yang berbeda. Dalam analisisnya, Podsakoff (2000) mengidentifikasi ada enam kelompok perilaku kepemimpinan transformasional, yaitu : articulating vision, providing an appropriate model (leading by example), fostering the acceptance of group goals, having high performance expectations, providing individualized support and provididing intellectual stimulation.

Pemimpin transformasional berupaya melakukan transforming of visionary menjadi visi bersama sehingga mereka (bawahan plus pemimpin) bekerja untuk mewujudkan visi menjadi kenyataan. Dengan kata lain, proses transformasional dapat terlihat melalui sejumlah perilaku kepemimpinan seperti; attributed charisma, idealized influence, inspirational motivation, intelectual stimulation, dan individualized consideration Bernard $\mathrm{M}$ Bass dan Bruce J, Avolio (2003), secara ringkas perilaku dimaksud sebagai berikut:

1. Attributed charisma, bahwa kharisma secara tradisional dipandang sebagai hal yang bersifat inheren dan hanya dimiliki oleh pemimpin-pemimpin kelas dunia. Penelitian membuktikan bahwa kharisma bisa saja dimiliki oleh pemimpin di level bawah dari sebuah organisasi. Pemimpin yang memiliki ciri tersebut, memperlihatkan visi, kemampuan, dan keahliannya serta tindakan yang lebih mendahulukan kepentingan organisasi dan kepentingan orang lain (masyarakat) daripada kepentingan pribadi.

2. Idealized Influence, pemimpin tipe ini berupaya mempengaruhi bawahannya melalui komunikasi langsung dengan menekankan pentingnya nilai-nilai, asumsi-asumsi, komitmen dan keyakinan, serta memiliki tekad untuk mencapai tujuan dengan senantiasa mempertimbangkan akibat-akibat moral dan etik dari setiap keputusan yang dibuat. Ia memperlihatkan kepercayaan pada cita-cita, keyakinan, dan nilai-nilai hidupnya.

3. Inspirational motivation, pemimpin transformasional bertindak dengan cara memotivasi dan memberikan inspirasi kepada bawahan melalui pemberian arti dan tantangan terhadap tugas bawahan. Bawahan diberi untuk berpartisipasi secara optimal dalam hal gagasan-gagasan, memberi visi mengenai keadaan organisasi masa depan yang menjanjikan harapan yang jelas dan transparan.

4. Intelectual stimulation, pemimpin mendorong bawahan untuk memikirkan kembali cara kerja dan mencari cara-cara kerja baru dalam menyelesaikan tugasnya. Pengaruhnya diharapkan, bawahan merasa pimpinan menerima dan mendukung mereka untuk memikirkan cara-cara kerja mereka, mencari cara-cara baru dalam menyelesaikan tugas, dan merasa menemukan cara-cara kerja baru dalam mempercepat tugas-tugas mereka. 


\section{Pengembangan Sumberdaya Manusia}

Pengembangan sumberdaya manusia semakin penting dan bermanfaat karena tuntutan pekerjaan atau jabatan, sebagai dampak kemajuan teknologi dan semakin ketatnya persaingan. Pengembangan (development) merupakan fungsi operasional kedua dari manajemen. Perubahan pengembangan karyawan (baru/lama) perlu dilakukan secara terencana dan berkesinambungan. Agar pengembangan dapat dilakukan dengan baik, terlebih dahulu ditetapkan suatu program pengembangan karyawan.

Siagian (2003:183) mengemukakan bahwa pengembangan menekankan pada peningkatan kemampuan melaksanakan tugas baru dimasa depan. Selain itu pengembangan merupakan investasi sumberdaya manusia untuk jangka panjang.

Hasibuan (2005:76) menjelaskan bahwa pengembangan adalah suatu usaha untuk meningkatkan kemampuan teknis, teoritis konseptual dan moral karyawan sesuai dengan kebutuhan pekerjaan/jabatan melalui pendidikan dan pelatihan.

Sikula dalam Hasibuan (2005:77) mengatakan bahwa pengembangan mengacu pada masalah staf dan personel adalah suatu proses pendidikan jangka panjang menggunakan suatu prosedur yang sistematis dan terorganisasi dengan mana manajer belajar pengetahuan konseptual dan teoritis untuk tujuan umum. Sedangkan latihan adalah suatu proses pendidikan jangka pendek dengan menggunakan prosedur yang sistematis dan terorganisir, dengan mana karyawan operasional belajar pengetahuan teknik pengerjaan dan keahlian untuk tujuan tertentu.

Pengembangan tersebut dilakukan untuk para pegawai melalui pendidikan dan pelatihan.

\section{Pendidikan}

Manusia membutuhkan pendidikan dalam kehidupannya. Pendidikan merupakan usaha agar manusia dapat mengembangkan potensi dirinya melalui proses pembelajaran dan atau cara lain yang di kenal dan di akui oleh masyarakat. Dalam Dictionary of Education dinyatakan bahwa pendidikan adalah :

a. Proses seseorang mengembangkan kemampuan, sikap dan tingkah laku lainnya didalam masyarakat tempat mereka hidup.

b. Proses sosial yang terjadi pada orang yang di harapkan pada pengaruh lingkungan yang terpilih dan terkontrak sehingga mereka dapat memperoleh perkembangan kemampuan sosial dan individu yang optimal.

Notoatmodjo (2003:23) mengemukakan bahwa pendidikan adalah suatu proses pengembangan kemampuan ke arah yang diinginkan oleh organisasi yang bersangkutan. Dari definisi di atas dapat ditarik kesimpulan bahwa pendidikan adalah suatu proses pembelajaran untuk meningkatkan potensi individu dan pengembangan diri individu dalam hal pengetahuan, kemampuan, sikap/tingkah laku individu. 
Siagian (2003:175) mengemukakan bahwa pendidikan adalah keseluruhan proses, teknik dan metode belajar mengajar dalam rangka mengalihkan suatu pengetahuan dari seseorang kepada orang lain sesuai standar yang telah ditetapkan. Sunarto (2004:159) mengemukakan bahwa pengertian pendidikan merupakan proses belajar yang dihayati sepanjang hidupnya baik dalam jalur pendidikan sekolah maupun di luar sekolah. Pendapat tersebut menunjukkan bahwa pendidikan adalah merupakan sesuatu yang dalami sepanjang hidup manusia.

Pelatihan (training) sering di bedakan dengan pendidikan (education). Pendidikan atau edukasi lebih luas lingkupnya, tujuannya adalah untuk mengembangkan individu. Biasanya pendidikan di anggap sebagai pendidikan formal di sekolah, akademi atau perguruan tinggi, sedangkan pelatihan lebih berorientasi kejuruan (vocationally oriented) dan berlangsung di dalam suatu lingkungan organisasi (Simamora, 2004:274).

Pendidikan menunjukkan suatu perluasan individu sehingga dia dapat dipersiapkan untuk menilai berbagai situasi dan memilih respon yang palimg tepat. Selain itu pula, tujuan pendidikan pegawai/karyawan adalah untuk mempersiapkan karyawan dalam menempati posisi atau jabatan yang baru melalui promosi dan pengembangan karir (Notoatmodjo, 2003:102).

\section{Pelatihan}

Handoyo (2000:27) berpendapat bahwa pada dasarnya pendidikan dan latihan yang diselenggarakan bagi pegawai adalah untuk meningkatkan prestasi kerja baik secara konseptual maupun secara teknis operasional, guna memperoleh produktivitas optimal dalam organisasi secara keseluruhan.

Pandangan tersebut menunjukkan bahwa penyelenggaraan diklat bagi pegawai berkaitan erat dengan upaya peningkatan kualitas sumberdaya manusia, dimana dengan pelaksanaan diklat diharapkan pegawai memiliki kapabilitas baik secara konseptual maupun secara teknis operasional, dalam melaksanakan tugas yang diembannya.

Sudiman (2004:50) mengemukakan bahwa jenis dan jenjang diklat dalam lingkungan instansi pemerintah adalah diklat prajabatan I, II dan III, SPAMA, SPAMEN, SPATI, ADUM, diklat fungsional dan diklat teknis, kursus-kursus dan lain sebagainya.

Sudiman (2004:45-48) mengemukakan bahwa dalam penjelasan pasal 31 Undang-Undang Nomor 8 tahun 1974 dinyatakan bahwa pengaturan pendidikan serta pengaturan dan penyelenggaraan latihan jabatan bagi Pegawai Negeri Sipil dimaksudkan agar terjamin keserasian pembinaan pegawai negeri sipil.

Pada pokoknya latihan jabatan dapat dibagi 2 (dua), yaitu :

1. Latihan pra jabatan; Latihan pra jabatan (pre service training) adalah suatu latihan yang diberikan kepada calon pegawai negeri sipil, dengan tujuan agar dapat terampil melaksanakan tugas yang akan dipercayakan kepadanya; 
Open Access at: http://ojs.uho.ac.id/index.php/PUBLICUHO/index

2. Latihan dalam jabatan; Latihan dalam jabatan (In service training) adalah suatu latihan yang bertujuan untuk meningkatkan kualitas, keahlian, kemampuan dan keterampilan.

Tujuan pendidikan dan pelatihan adalah :

1. Meningkatkan kesetiaan dan ketaatan pegawai negeri sipil kepada Pancasila, UndangUndang Dasar 1945, negara dan pemerintah Republik Indonesia.

2. Menanamkan kesamaan pola pikir yang dinamis dan bernalar agar memiliki wawasan yang komprehensif untuk melaksanakan tugas umum pemerintahan dan pembangunan.

3. Memantapkan semangat pengabdian yang berorientasi pada pelayanan, pengayoman dan pengembangan partisipasi masyarakat.

4. Meningkatkan pengetahuan, keahlian dan/atau keterampilan serta pembentukan sedini mungkin kepribadian pegawai negeri sipil.

Sasaran pendidikan dan pelatihan adalah tersedianya pegawai negeri sipil yang memiliki kualitas tertentu guna memenuhi salah satu persyaratan untuk diangkat dalam jabatan tertentu. seseorang Pegawai Negeri Sipil hanya dapat diangkat dalam jabatan tertentu setelah memenuhi persyaratan yang ditetapkan jabatan tersebut. Salah satu persyaratan adalah mengikuti dan lulus pendidikan dan pelatihan sesuai dengan jabatan yang akan dipangkunya. Pendidikan dan pelatihan terdiri dari :

A. Pendidikan dan pelatihan pra jabatan

Pendidikan dan pelatihan pra jabatan adalah pendidikan dan pelatihan yang dipersyaratkan bagi calon Pegawai Negeri Sipil yang diangkat menjadi pegawai negeri sipil. Pendidikan dan pelatihan pra jabatan dimaksudkan untuk melakukan pembentukan sikap mental, kesempatan fisik dan disiplin serta untuk memenuhi kebutuhan kemampuan, keahlian dan/atau keterampilan bagi calon Pegawai Negeri Sipil yang diperlukan untuk menduduki jabatan negeri. Pendidikan dan pelatihan pra jabatan terdiri dari :

1)Diklat prajabatan Golongan III

2)Diklat prajabatan Golongan II

3)Diklat prajabatan Golongan I.

B. Pendidikan dan pelatihan dalam jabatan.

Pendidikan dan pelatihan dalam jabatan adalah pendidikan dan pelatihan bagi Pegawai Negeri Sipil terdiri dari:

\section{Pendidikan dan pelatihan struktural}

Pendidikan dan pelatihan struktural adalah pendidikan dan pelatihan yang dipersyaratkan bagi Pegawai Negeri Sipil yang akan diangkat dalam jabatan struktural.

Pendidikan dan pelatihan ini merupakan salah satu syarat yang harus dipenuhi bagi Pegawai Negeri Sipil untuk dapat diangkat dalam jabatan struktural di samping syarat lain yang ditentukan dalam perundang-undangan yang berlaku. Pendidikan dan 
pelatihan ini bersifat selektif dan diikuti atas dasar penugasan. Oleh karenanya, bukan merupakan fasilitas yang bersifat terbuka dan dapat diminta sebagai hak.

Pendidikan dan pelatihan struktural memiliki 3 (tiga) jenjang, yaitu :

1) Pendidikan dan pelatihan staf dan pimpinan administrasi tingkat pertama yang selanjutnya disebut Diklat SPAMA, yaitu pendidikan dan pelatihan yang dipersyaratkan bagi Pegawai Negeri Sipil yang terpilih dan memiliki kemampuan untuk diangkat dalam jabatan struktural eselon III.

2) Pendidikan dan pelatihan staf dan pimpinan administrasi tingkat menengah (SPAMEN) yang selanjutnya bagi Pegawai Negeri Sipil yang terpilih dan memiliki kemampuan untuk diangkat dalam jabatan struktural eselon II.

3) Pendidikan dan pelatihan staf dan pimpinan tingkat tinggi yang selanjutnya disebut Diklat SPATI, yaitu pendidikan dan pelatihan Pegawai Negeri Sipil yang telah menduduki jabatan struktural eselon II dan terpilih serta memiliki kemampuan untuk diangkat dalam jabatan struktural eselon I. Oleh karena diklat struktural tersebut berjenjang, maka salah satu persyaratan untuk mengikuti jenjang diklat yang lebih tinggi, kepada pesertanya dipersyaratkan telah lulus dalam jenjang diklat di bawahnya.

\section{Pendidikan dan pelatihan administrasi umum}

Pendidikan dan pelatihan administrasi umum (Adum) adalah pendidikan dan pelatihan yang dipersyaratkan bagi Pegawai Negeri Sipil yang terpilih dan memiliki kemampuan untuk diangkat dalam jabatan eselon IV dan juga yang akan diangkat dalam jabatan fungsional.

\section{Pendidikan dan pelatihan fungsional}

Pendidikan dan pelatihan fungsional adalah pendidikan dan pelatihan yang dipersyaratkan bagi Pegawai Negeri Sipil yang telah menduduki jabatan fungsional. Pendidikan dan pelatihan fungsional merupakan pendidikan dan pelatihan yang memberikan bekal bagi Pegawai Negeri Sipil untuk meningkatkan pengetahuan dan keterampilan yang diperlukan dalam menduduki jabatan fungsional dan dapat juga diikuti oleh pejabat stuktural.

\section{Pendidikan dan pelatihan teknis}

Pendidikan dan pelatihan teknis adalah pendidikan dan pelatihan yang diselenggarakan untuk memberi keterampilan atau penguasaan pengetahuan dibidang teknis tertentu kepada Pegawai Negeri Sipil, sehingga mampu melaksanakan tugas dan tanggung jawab yang diberikan dengan sebaik-baiknya. Pendidikan dan pelatihan teknis dapat dilakukan secara berjenjang sesuai dengan tingkat dan jenis pekerjaan Pegawai Negeri Sipil yang bersangkutan. 


\section{Kinerja}

Setiap pegawai diharapkan dapat memiliki kinerja yang baik dalam melaksanakan pekerjaannya. Dalam hal ini tentunya tugas-tugas yang dibebankan kepadanya dapat terselesaikan dengan baik dalam arti disertai kecakapan, disiplin serta tanggung jawab yang tinggi. Apabila keadaan ini tercipta akan berhubungan sekali terhadap hasilnya, baik dalam kuantitas maupun kualitasnya. Disamping itu pimpinan juga harus selalu berusaha meningkatkan kinerja bawahannya.

Kinerja dapat dartikan sebagai kemampuan kerja atau hasil kerja. Winardi (2006:82) mengemukakan bahwa kinerja adalah kemampuan kerja seorang pegawai/pegawai dalam menyelesaikan tugas yang dibebankan kepadanya secara berhasil dan berdaya guna. Dharma (2005:1) mengemukakan bahwa kinerja atau prestasi kerja adalah sesuatu yang dikerjakan atau produk jasa-jasa yang diberikan atau yang dihasilkan oleh seseorang atau sekelompok orang. Kata prestasi merupakan terjemahan dari bahasa Inggris, performance. Dalam bahasa Indonesia istilah prestasi kerja diartikan sebagai ungkapan kemampuan yang didasari oleh pengetahuan, sikap, dan keterampilan dalam menghasilkan sesuatu.

Pengertian tersebut menunjukkan bahwa kinerja merupakan hasil kerja atau kemampuan kerja seseorang yang dibentuk melalui pengetahuan yang dimiliki, sikap maupun keterampilan.

Sesuai pengertian kinerja di atas jelaslah bahwa hasil kerja dari seseorang atau sekelompok orang mempunyai perbedaan, sehingga dibutuhkan penilaian atas kinerja tersebut. Penilaian kinerja dalam rangka pengembangan sumberdaya manusia adalah sangat penting artinya karena kegiatan ini dapat memperbaiki keputusan pimpnan dan memberikan umpan balik kepada bawahan tentang kegiatan mereka.

Husnan dan Ranupanjdojo (2000:30) mengemukakan bahwa penilaian kinerja adalah untuk menentukan apakah suatu pekerjaan bisa dikerjakan atau diselesaikan dengan baik, maka deskripsi jabatan akan sangat membantu dalam penentuan sasaran pekerjaanya.

Tiffin yang dikutip Manullang (2001:118) memberi pembatasan bahwa penilaian pegawai adalah penilaian yang sistematis dari pada seorang pegawai oleh atasannya atau beberapa orang ahli lainnya yang faham akan pelaksanaan pekerjaan yang dilakukan oleh pegawai tersebut.

Handoko (2003:135) mengemukakan bahwa penilaian kinerja adalah proses melalui mana organisasi-organisasi mengevaluasi atau menilai prestasi pegawainya. Kegiatan ini dapat mempengaruhi keputusan-keputusan personalia dan memberikan umpan balik kepada para pegawai tentang pelaksanaan kerja mereka. Adapun kegunaan penilaian kinerja adalah sebagai berikut : 
1. Mendorong orang ataupun pegawai agar berperilaku positif atau memperbaiki tindakan mereka yang di bawah standar.

2. Sebagai bahan penilaian bagi manajemen apakah pegawai tersebut telah bekerja dengan baik.

3. Memberikan dasar yang kuat bagi pembuatan kebijakan peningkatan organisasi.

Sesuai dengan uraian tersebut, dapat disimpulkan bahwa penilaian kinerja adalah proses suatu organisasi mengevaluasi atau menilai kerja pegawainya. Apabila penilaian kinerja dilaksanakan dengan baik, tertib, dan benar akan dapat membantu meningkatkan motivasi kerja sekaligus dapat meningkatkan loyalitas para anggota organisasi yang ada di dalamnya, dan apabila ini terjadi akan menguntungkan organisasi itu sendiri. Oleh karena itu penilaian prestasi kerja perlu dilakukan secara formal dengan kriteria-kriteria yang telah ditetapkan oleh organisasi secara obyektif.

Ruky (2002:203) memberikan gambaran tentang faktor-faktor penilaian kinerja yang berorientasi pada individu yaitu : 1) pengabdian, 2) kejujuran, 3) kesetiaan, 4) prakarsa, 5) kemavan bekerja, 6) kerjasama, 7) prestasi kerja, 8) pengembangan, 9) tanggung jawab, dan 10) disiplin kerja. Unsur-unsur yang dinilai oleh pimpinan terhadap para bawahannya.

Pendapat tersebut menunjukkan bahwa faktor-faktor penilaian kinerja yang berorientasi pada individu ada 10 jenis.

Bernardin dan Rusel dalam Ruky (2002:340) mengemukakan lima kriteria primer yang dapat digunakan untuk mengukur kinerja, yaitu:

a. Quality (kualitas kerja), merupakan tingkat sejauh mana proses atau hasil pelaksanaan pekerjaan mendekati kesernpurnaan atau mendekati tujuan yang diharapkan. Indikator dari kualitas kerja meliputi : kualitas hasil pekerjaan yang sesuai standar pimpinan, prosedur pelaksanaan tugas/pekerjaan yang ditetapkan serta teguran pimpinan atas mutu hasil pekerjaan.

b. Quantity (kuantitas kerja), merupakan jumlah yang dihasilkan, misalnya jumlah rupiah, jumlah unit atau jumlaj siklus kegiatan yang diselesaikan. Indikator dari kuantitas kerja meliputi : volume kerja yang ditetapkan oleh pimpinan, fasilitas/sarana pelaksanaan tugas sesuai standar yang diharapkan pimpinan dan teguran pimpinan atas pencapaian volume hasil kerja.

c. Timeliness (ketepatan waktu), merupakan lamanya suatu kegiatan diselesaikan pada waktu, yang dikehendaki, dengan memperhatikan jumlah output lain serta waktu yang tersedia untuk kegiatan lain. Indikator dari ketepatan waktu meliputi : tepat waktu dalam memulai, menyelesaikan dan teguran pimpinan atas keterlambatan penyelesaian tugas.

d. Need for supervision (kemandirian kerja), kemampuan pegawai untuk dapat melaksanakan fungsi pekerjaan tanpa memerlukan pengawasan seorang supervisor 
untuk mencegah tindakan yang tidak diinginkan. Indikator dari kebutuhan pengawasan meliputi : membutuhkan pertolongan rekan kerja dalam melaksanakan pekerjaan, kadang-kadang membutuhkan bimbingan dari atasan dalam pelaksanaan pekerjaan serta melaksanakan pekerjaan secara mandiri tanpa bantuan dari siapapun.

e. Interpersonal impact (hubungan individual), kemampuan seorang pegawai untuk memelihara harga diri, nama baik dan kemampuan bekerjasama diantara rekan kerja dan bawahan. Indikator dari hubungan individual meliputi : percaya diri dalam melaksanakan tugas pokok dan tanggungjawab, menginginkan untuk menyelesaikan pekerjaan dengan hasil yang maksimal dan selalu bekerjasama dengan rekan kerja.

Pendapat tersebut menunjukkan bahwa ada lima indikator yang dapat dijadikan dasar untuk menilai kinerja seseorang, yaitu : kualitas kerja, kuantitas kerja, ketepatan waktu, kemandirian kerja dan hubungan individual.

Para pimpinan organisasi sangat menyadari adanya perbedaan kinerja antara satu pegawai dengan pegawai lainnya yang berada di bawah pengawasannya. Walaupun pegawai-pegawai bekerja pada tempat yang sama namun kinerja mereka tidaklah sama.

\section{METODOLOGI}

\section{Lokasi Penelitian}

Lokasi penelitian ini adalah Dinas Pekerjaan Umum Provinsi Sulawesi Tenggara dengan pertimbangan bahwa kinerja pegawai pada instansi tersebut belum sepenuhnya sesuai yang diharapkan.

\section{Populasi dan Sampel}

Populasi penelitian ini adalah pegawai staf Dinas Pekerjaan Umum Provinsi Sulawesi Tenggara yaitu sebanyak 621 orang (diluar pimpinan, kepala bidang dan kepala seksi) yang terdistribusi pada tingkat pendidikan SLTA sebanyak 228 orang, Diploma 100 orang, Sarjana 257 orang dan Magister sebanyak 36 orang. Sampel penelitian dipilih secara acak berkelompok (cluster random sampling) sesuai tingkat pendidikan. Adapun besarnya sampel dihitung dengan menggunakan rumus Taro Yamane. Dengan demikian sampel penelitian ini sebanyak 88 orang.

\section{Teknik Analisis Data}

Pengaruh kepemimpinan transformasional dan pengembangan sumberdaya manusia terhadap kinerja pegawai Dinas Pekerjaan Umum Provinsi Sulawesi Tenggara dianalisis dengan menggunakan analisis regresi linear ganda. Hasil perhitungan regresi selanjutnya 
diuji dengan menggunakan uji † dan uji F dengan menggunakan tingkat keyakinan 0,95 atau taraf nyata $\alpha=0,05$.

\section{HASIL DAN PEMBAHASAN}

\section{Hasil Penelitian}

Tabel 1. Hasil Analisis Regresi Linear Berganda

\begin{tabular}{lcccc}
\hline \multicolumn{1}{c}{ Variabel } & $\begin{array}{c}\text { Koefisien Regresi } \\
(\mathrm{b})\end{array}$ & $\begin{array}{c}t_{\text {hitung }} \\
(\mathrm{db}=85)\end{array}$ & $\begin{array}{c}\text { Probabilitas Parsial } \\
(\mathrm{sig})\end{array}$ & Korelasi \\
\hline 1. Kepemimpinan Transformasional $\left(\mathrm{X}_{1}\right)$ & 0,753 & 9,170 & 0,000 & 0,949 \\
2. Pengembangan SDM $\left(\mathrm{X}_{2}\right)$ & 0,214 & 2,601 & 0,011 & 0,904 \\
\hline Constanta (a) & 3,216 & & & \\
Koefisien Korelasi (R) & 0,953 & & \\
Koefisien determinasi (R square) & 0,908 & & \\
F hitung & 421,575 & & \\
Probabilitas simultan & 0,000 & & \\
\end{tabular}
Sumber : Data Diolah tahun 2019

\section{Persamaan regresi}

Berdasarkan hasil analisis regresi pada tabel 4.18 di atas, maka persamaan garis regresi linear ganda dapat diketahui sebagai berikut :

$$
\begin{aligned}
& Y=a+b_{1} X_{1}+b_{2} X_{2} \\
& Y=3,216+0,753 X_{1}+0,214 X_{2}
\end{aligned}
$$

\section{Koefisien Regresi}

Dimaksudkan untuk mengetahui besarnya pengaruh kepemimpinan transformasional dan pengembangan sumberdaya manusia terhadap kinerja pegawai pada Dinas Pekerjaan Umum Provinsi Sulawesi Tenggara. Sesuai dengan data pada tabel 4.18 diketahui bahwa:

a. Nilai koefisien regresi $\left(b_{1}\right)=0,753$. Ini menunjukkan bahwa besarnya pengaruh kepemimpinan transformasional terhadap kinerja pegawai adalah $75,30 \%$ persen dengan asumsi faktor lain dianggap tetap.

b. Nilai koefisien regresi $\left(b_{2}\right)=0,214$. Ini berarti bahwa besarnya pengaruh pengembangan sumberdaya manusia terhadap kinerja pegawai adalah 21,40\% dengan asumsi faktor lain dianggap tetap.

\section{Koefisien determinasi ( $R$ square)}

Berdasarkan hasil perhitungan nilai koefisien determinasi yang diperoleh sebesar 0,908, ini berarti bahwa variasi baiknya kinerja pegawai pada Dinas Pekerjaan Umum Provinsi Sulawesi Tenggara dipengaruhi oleh kepemimpinan transformasional dan pengembangan sumberdaya manusia sebesar $90,80 \%$. Selebihnya yaitu sebesar $9,20 \%$ dipengaruhi oleh faktor lain yang tidak dimasukkan kedalam model penelitian ini.

\section{Uji $t$}

Sesuai dengan hasil analisis komputer (SPSS program) dapat diketahui bahwa:

a. Kepemimpinan transformasional $\left(X_{1}\right)$ secara parsial berpengaruh signifikan terhadap kinerja pegawai pada Dinas Pekerjaan Umum Provinsi Sulawesi Tenggara (Y). Hal ini 
ditunjukkan oleh hasil uji † pada tingkat kepercayaan 0,95 atau taraf nyata $\alpha=0,05$ derajat bebas 85, dimana thitung $=9,170>t_{\text {tabel }}$ yaitu 1,671-1,684 (lampiran 15) atau dengan nilai probabilitas $=0,000<0,05$. Dengan demikian maka hipotesis satu yaitu: Kepemimpinan transformasional berpengaruh signifikan terhadap kinerja pegawai dapat diterima.

b. Pengembangan sumberdaya manusia $\left(X_{2}\right)$ secara parsial berpengaruh signifikan terhadap kinerja pegawai pada Dinas Pekerjaan Umum Provinsi Sulawesi Tenggara (Y). Hal ini ditunjukkan oleh hasil uji t pada tingkat kepercayaan 0,95 atau taraf nyata $\alpha=0,05$ derajat bebas 85 , dimana thitung $=2,601>$ tabel yaitu 1,671-1,684 atau dengan nilai probabilitas $=0,011<0,05$. Dengan demikian maka hipotesis dua yaitu : Pengembangan sumberdaya manusia berpengaruh signifikan terhadap kinerja pegawai dapat diterima.

Sesuai hasil uji t ini maka dapat diketahui bahwa faktor yang paling dominan mempengaruhi kinerja pegawai adalah faktor kepemimpinan transformasional dengan nilai thitung tertinggi yaitu sebesar 9,170.

\section{Uji $\mathbf{F}$}

Kepemimpinan transformasional $\left(X_{1}\right)$ dan pengembangan sumberdaya manusia $\left(X_{2}\right)$ secara bersamaan berpengaruh signifikan terhadap kinerja pegawai pada Dinas Pekerjaan Umum Provinsi Sulawesi Tenggara (Y). Hal ini ditunjukkan oleh hasil uji $F$ pada tingkat kepercayaan 0,95 atau taraf nyata $\alpha=0,05$ derajat bebas 85 , dimana $F_{\text {hitung }}=421,575>F_{\text {tabel }}$ yaitu 3,09-3,11 (lampiran 16) atau dengan nilai probabilitas $=0,000<0,05$. Ini berarti bahwa faktor kepemimpinan transformasional dan pengembangan sumberdaya manusia secara simultan berpengaruh signifikan terhadap kinerja pegawai pada Dinas Pekerjaan Umum Provinsi Sulawesi Tenggara. Dengan demikian maka hipotesis tiga yaitu : Kepemimpinan transformasional dan pengembangan sumberdaya manusia secara simultan berpengaruh signifikan terhadap kinerja pegawai dapat diterima.

\section{Pembahasan}

Secara deskriptif kepemimpinan transformasional oleh responden di nilai berada pada kondisi baik apabila diamati dari dimensi karisma, pengaruh idealisme, motivasi inspiratif serta stimulasi intelektual.

Hasil penilaian tersebut, didasarkan pada hasil analisis deskriptif data yang menunjukkan nilai skor jawaban responden yaitu rata-rata 3,96 (berada pada interval penilaian 3,41-4,21) yakni berada pada kategori baik.

Baiknya kepemimpinan transformasional berdasarkan hasil kuesioner memberikan implikasi atau pengaruh yang signifikan terhadap kinerja pegawai Dinas Pekerjaan Umum Provinsi Sulawesi Tenggara. Hal ini diperkuat oleh hasil uji statistik yaitu uji † yang menunjukkan bahwa nilai thitung $=9,170>t_{\text {tabel }}$ yaitu 1,671-1,684 atau dengan nilai probabilitas $=0,000<0,05$. Ini 
berarti bahwa apabila kepemimpinan transformasional yang dilaksanakan pimpinan baik maka kinerja pegawai akan menjadi baik.

Temuan penelitian ini sejalan dengan teori yang dikemukakan oleh Gerry Yulk (2007:320) bahwa para pemimpin transformasional membuat para pengikut menjadi lebih menyadari kepentingan dan nilai dari pekerjaan dan membujuk pengikut untuk tidak mendahulukan kepentingan diri sendiri demi organisasi. Para pemimpin mengembangkan keterampilan dan keyakinan pengikut untuk menyiapkan mereka mendapatkan tanggungjawab yang lebih banyak dalam sebuah organisasi yang memberikan wewenang. Para pemimpin memberikan dukungan dan dorongan saat diperlukan untuk mempertahankan antusiasme dan upaya di hadapan halangan, kesulitan dan kelelahan. Hasil dari pengaruh ini, para pengikut merasa percaya dan hormat terhadap pemimpin, dan mereka termotivasi untuk melakukan lebih daripada yang diharapkan sebelumnya sehingga kinerjanya lebih menjadi baik. Oleh karena itu antara kepemimpinan transformasional memiliki hubungan yang erat dengan perbaikan kinerja pengikut. Disamping itu, hasil penelitian ini juga mendukung hasil penelitian empiris yang dilakukan oleh Inand Irojasa (2008) bahwa terdapat pengaruh positif dan signifikan antara persepsi perilaku kepemimpinan transformasional dengan kinerja pegawai. Juga memperkuat hasil penelitian empiris yang dilakukan oleh Aksan (2010) bahwa gaya kepemimpinan tranformasional berpengaruh signifikan terhadap kinerja karyawan.

Secara deskriptif pengembangan sumberdaya manusia oleh responden di nilai berada pada kondisi baik apabila diamati dari dimensi pendidikan dan latihan.

Temuan tersebut di dasarkan pada hasil analisis deskriptif data yang menunjukkan penilaian dengan nilai rata-rata 4,07 (berada pada interval penilaian 3,41-4,21) yakni berada pada kategori baik.

Baiknya pengembangan sumberdaya manusia melalui pendidikan dan latihan yang di dasarkan pada hasil kuesioner memberikan pengaruh yang signifikan terhadap kinerja pegawai. Hal ini diperkuat oleh hasil analisis statistik yaitu uji † (uji pengaruh secara parsial) yang menunjukkan bahwa nilai thitung $=2,601>t_{\text {tabel }}$ yaitu 1,671-1,684 atau dengan nilai probabilitas $=0,011<0,05$. Ini berarti bahwa apabila pengembangan sumberdaya manusia baik maka akan meningkatkan kinerja pegawai. Adapun besaran pengaruh dari baiknya pengembangan sumberdaya manusia terhadap peningkatan kinerja yaitu 0,949.

Temuan penelitian ini sejalan dengan teori yang dikemukakan oleh Handoyo (2000:27) bahwa pada dasarnya pendidikan dan latihan yang diselenggarakan bagi pegawai adalah untuk meningkatkan prestasi kerja baik secara konseptual maupun secara teknis operasional, guna memperoleh produktivitas optimal dalam organisasi secara keseluruhan. Pandangan tersebut menunjukkan bahwa penyelenggaraan diklat bagi pegawai berkaitan erat dengan upaya peningkatan kualitas sumberdaya manusia, dimana dengan pelaksanaan diklat 
diharapkan pegawai memiliki kapabilitas baik secara konseptual maupun secara teknis operasional, dalam melaksanakan tugas yang diembannya. Hasil penelitian ini juga mendukung hasil penelitian empiris yang dilakukan oleh Mingguyanti (2010) bahwa pengembangan sumberdaya manusia berhubungan signifikan dengan kinerja pegawai pada Sekretariat Daerah Kabupaten Kolaka.

Hasil penelitian menunjukkan bahwa secara simultan kepemimpinan transformasional dan pengembangan sumberdaya manusia berpengaruh signifikan terhadap kinerja pegawai. Hal ini diperkuat melalui hasil uji F yang menunjukan bahwa Fhitung $=421,575>F_{\text {tabel }}$ yaitu 2,702,72 atau dengan nilai probabilitas $=0,000<0,05$. Artinya bahwa apabila kepemimpinan transformasional dan pengembangan sumberdaya manusia berada pada kondisi yang baik maka akan meningkatkan kinerja pegawai apabila diamati dari dimensi kualitas, kuantitas kerja, ketepatan waktu menyelesaikan pekerjaan, kemandirian kerja serta hubungan individual. Hasil penelitian tentang kinerja pegawai secara deskriptif menunjukkan bahwa kinerja pegawai berada pada kondisi baik yang ditandai dengan perolehan nilai skor ratarata 4,02 (berada pada interval penilaian 3,41-4,21).

Hasil penelitian ini, diperkuat pula melalui hasil analisis dari program SPSS yang menunjukkan nilai koefisien korelasi ganda sebesar 0,953 yang berarti bahwa kepemimpinan transformasional dan pengembangan sumberdaya manusia berhubungan positif dan sangat kuat dengan kinerja pegawai. Adapun besarnya pengaruh kepemimpinan transformasional dan pengembangan sumberdaya manusia terhadap perubahan peningkatan kinerja pegawai ditunjukkan oleh nilai koefisien determinasi sebesar 0,908 yang berarti bahwa kinerja pegawai dipengaruhi oleh faktor kepemimpinan transformasional dan pengembangan sumberdaya manusia dimana besar pengaruhnya adalah 90,80\% dengan asumsi faktor lain tetap.

Pengamatan penulis menunjukkan bahwa baik kepemimpinan transformasional maupun pengembangan sumberdaya manusia melalui pendidikan dan latihan yang terimplementasi dengan baik pada akhirnya mempengaruhi terciptanya perbaikan kinerja pegawai dimana kinerja tersebut menjadi baik.

\section{KESIMPULAN}

Berdasarkan hasil penelitiandan pembahasan maka dapat disimpulkan bahwa:

1. Kepemimpinan transformasional yang diamati dari dimensi karisma, pengaruh idealisme, motivasi inspiratif serta stimulasi intelektual berpengaruh signifikan terhadap kinerja pegawai Dinas Pekerjaan Umum Provinsi Sulawesi Tenggara. Ini berarti bahwa perubahan perilaku kepemimpinan ke arah yang baik menyebabkan perubahan kinerja ke arah yang lebih baik pula. 
2. Pengembangan sumberdaya manusia yang diamati melalui dimensi pendidikan dan pelatihan berpengaruh signifikan terhadap kinerja pegawai Dinas Pekerjaan Umum Provinsi Sulawesi Tenggara. Artinya bahwa perubahan pengembangan sumberdaya manusia kearah yang baik dapat memacu perbaikan kinerja pegawai kearah yang lebih baik pula.

3. Kepemimpinan transformasional dan pengembangan sumberdaya manusia secara simultan berpengaruh signifikan terhadap kinerja pegawai Dinas Pekerjaan Umum Provinsi Sulawesi Tenggara. Artinya perubahan kepemimpinan transformasional dan pengembangan sumberdaya manusia kearah yang baik, meningkatkan kinerja pegawai apabila diamati dari dimensi kualitas, kuantitas kerja, ketepatan waktu menyelesaikan pekerjaan, kemandirian kerja serta hubungan individual.

\section{SARAN}

Berdasarkan hasil penelitian dan pembahasan, maka peneliti memberikan saran yaitu:

1. Kepala Dinas Pekerjaan Umum Provinsi Sulawesi Tenggara sebaiknya memperhatikan aspek kepemimpinan transformasional karena hal tersebut dapat memacu peningkatan kinerja pegawai.

2. Perlunya memperhatikan aspek pengembangan pegawai melalui pendidikan dan latihan karena hal tersebut dapat memacu peningkatan kinerja pegawai

3. Bagi pegawai agar senantiasa mempertahankan dan meningkatkan kinerjanya dengan melaksanakan tugas pokok dan tanggungjawab dengan sebaik-baiknya sebagai abdi negara dan masyarakat.

4. Rekomendasi bagi peneliti masa yang akan datang; karena penelitian ini hanya menggunakan dua variabel yang diduga mempengaruhi kinerja pegawai, maka bagi peneliti selanjutnnya kiranya dapat mengembangkan penelitian ini pada variabel lain yang dapat mempengaruhi kinerja pegawai di luar dari kepemimpinan transformasional dan pengembangan sumberdaya manusia. Variabel lain dimaksud adalah kemampuan, keterampilan, tanggungjawab dan disiplin.

\section{DAFTAR PUSTAKA}

Aditiawan. Chandra, 2002. Visionary Leadership : Gaya Kepemimpinan Untuk Organisasi Masa Depan. Manajemen Usahawan Indonesia, Jakarta.

Bass B, Waldman, D.A., Avolio, B.J and Bebb, M. 2002. Transformational Leadership and The Falling Dominoes Effect, Group \& Organization Studies. dan Avolio, B.J. 2004. Improving Leadership Effectiveness Through Transformational Leadership, California, USA 7 Sage.

B 2005. Leadership and Performance Beyond Expectations. New York : The free Press. 
Volume 2 Number 4 (November-January), (2019) pp.1-20

Open Access at: http://ojs.uho.ac.id/index.php/PUBLICUHO/index

.........., B.M., dan Avolio, B.J. 2006, Transformational Leadership Development : Manual for the Multifactor, Consulting Psychologists Press, Palo Alto, CA.

Bennis, W.G and B. Nanus. 2000. Leaders: The Strategies for Taking Charge. New York: Harper and Row.

Bersona, Yair \& Avolio, Bruce. J. 2004. Transformational Leadership and The Dissemination of Organizational Goals : A Case Study of a Telecommunication Firm.

Brown, F. William., Bryant, Scott E., \& Reilley, Michael D. 2006. Does Emotional Intelligence-as Measured by the EQI-Influence Ke Transformational Leadership and/or Desirable Outcomes? Leadership \& Organizational Development Journal.

Bryman, A. 2002. Charisma and Leadership in Organizations. London : Sage Publications.

2006. Leadership in Organizations, in Clagg, S.P., Hardy, C and Nord, W.R. (Eds). Handbook of Organizations Studies, Sage, Thousand Oaks, CA.

Cannella, A.A., \& Monroe, M. J. 2002. Contrasting Perspectives on Strategic Leaders : Toward A More Realistic View of Top Managers. Journal.

Dharma, Agus, 2005, Manajemen Prestasi Kerja, Ghalia Indonesia, Jakarta.

Handoyo, 2000. Berbagai Macam Teknik Pembinaan Tenaga Kerja, Batara Karya Aksara, Jakarta.

Handoko, Hani T., 2003, Manajemen Personalia dan Sumberdaya Manusia, BPFE., UGM., Yogyakarta.

Hasibuan S.P Melayu, 2005. Manajemen Sumberdaya Manusia Dasar dan Kunci Keberhasilan. CV. Haji Masagung. Jakarta

Hunt, J.G. 2004. "Tranformational/charismatic of the field : an historical essay", Leadership Quarterly.

Husnan, Suad dan Ranupandjoyo, Heidjrachman, 2000, Manajemen Personalia, BPFE, UGM., Yogyakarta.

Lowe, K.B., Kroeck, K.G., \& Sivasubramaniam, N. 2006. Effectiveness Correlates of Transformational and Transactional Leadership: A Meta-Analytic Review of The MLQ Literature. The Kepemimpinan Quarterly.

Manullang, M., 2001, Manajemen Personalia, Aksara Baru, Jakarta.

Notoadmojo, S. 2003, Metodologi Penelitian, Rineka Cipta, Jakarta.

Rafferty, Alannah, E., \& Griffin, Mark, A. 2004. Sub Variabelons of Transformational Leadership: Conceptual and Empirical Extensions. The Leadership Quarterly.

Ruky Achmad S., 2002, Sistem Manajemen Kinerja. di download dari :http//www.geocitios.com.

Santosa Purbaya Budi dan Ashari, 2005. Analisis Statistik dengan Microsoft Excel dan SPSS. Andi Offset, Yogyakarta.

Siagian, P. Sondang, 2002, Teori dan Praktek Kepemimpinan, Rineka Cipta, Jakarta. 2003. Manajemen Sumberdaya Manusia, PT. Bumi Aksara. Jakarta

Simamora Henry, 2004, Manajemen Sumberdaya Manusia, STIE., YKPN, Yogyakarta.

Shamir, B., House, R.J., \& Arthur, M.B. 2003. The Motivational Effects of Charismatic Leadership: A Self-Concept Based Theory. Organization Science. 

Pada Dinas Pekerjaan Umum Provinsi Sulawesi Tenggara

Volume 2 Number 4 (November-January), (2019) pp.1-20

Sudiman, 2004. Administrasi Kepagawaian, Lembaga Administrasi Negara, RI., Jakarta.

Winardi, 2006. Manajemen Perkantoran dan Pengawasan, Alumni Bandung.

Yukl, Gary. 2007. Kepemimpinan dalam Organisasi, Edisi Bahasa Indonesia, PT. Indeks, Jakarta. 